Correspondence

Philippe Lebaron

lebaron@obs-banyuls.fr

\section{Nisaea denitrificans gen. nov., sp. nov. and Nisaea nitritireducens sp. nov., two novel members of the class Alphaproteobacteria from the Mediterranean Sea}

\author{
Laurent Urios, ${ }^{1,2}$ Valérie Michotey, ${ }^{3}$ Laurent Intertaglia, ${ }^{1}$ \\ Françoise Lesongeur ${ }^{4}$ and Philippe Lebaron ${ }^{1}$
}

\author{
1Observatoire Océanologique de Banyuls, Laboratoire ARAGO, Université Pierre et Marie \\ Curie - Paris 6, UMR 7621, F-75005 Paris, France \\ ${ }^{2}$ Institut National des Sciences de I'Univers (INSU) CNRS, UMR 7621, BP 44, F-66650 \\ Banyuls-sur-Mer, France \\ ${ }^{3}$ Laboratoire de Microbiologie, de Géochimie et d'Ecologie Marines, CNRS UMR 6117, Centre \\ d'Océanologie de Marseille, Campus de Luminy, Case 901, 13288 Marseille Cedex 9, France \\ ${ }^{4}$ Laboratoire de Microbiologie des Environnements Extrêmes, UMR 6197, IFREMER, Centre de \\ Brest, BP 70, 29280 Plouzané, France
}

\begin{abstract}
Two novel Gram-negative bacteria, designated strains DR41_21 ${ }^{\top}$ and DR41_18 ${ }^{\top}$, were isolated from coastal, surface waters of the north-western Mediterranean Sea. The cells were motile, pleomorphic rods, $2.9 \mu \mathrm{m}$ long and $0.9 \mu \mathrm{m}$ wide and formed cream colonies on marine agar medium. The $\mathrm{G}+\mathrm{C}$ content of the genomic DNA was $60 \mathrm{~mol} \%$. Phylogenetic analysis of $16 \mathrm{~S}$ rRNA gene sequences positioned the isolates in the class Alphaproteobacteria within the family Rhodospirillaceae. The 16S rRNA gene sequence similarity of the two strains was $98.8 \%$ but DNA-DNA hybridization indicated only $55 \%$ relatedness. Strain DR41_21 ${ }^{\top}$ was able to denitrify and possessed nirK and nos $Z$ genes, unlike strain DR41_18 ${ }^{\top}$, which possessed only nirK. These isolates represent two novel species of a new genus, Nisaea gen. nov., for which the names Nisaea denitrificans sp. nov. and Nisaea nitritireducens sp. nov. are proposed. The type strain of Nisaea denitrificans is DR41_21 ${ }^{\top}\left(=\mathrm{DSM} 18348^{\top}=\mathrm{CIP} 109265^{\top}=\mathrm{OOB} 129^{\top}\right)$ and the type strain of Nisaea nitritireducens is DR41_18 $\left(=\mathrm{DSM} 19540^{\top}=\mathrm{CIP} 109601^{\top}=\right.$ OOB $\left.128^{\top}\right)$.
\end{abstract}

Denitrification is a respiratory process in which nitrogen compounds are used as alternative electron acceptors for energy production when oxygen is limited. This stepwise reaction occurs in a wide variety of micro-organisms ranging from Archaea to Gram-positive bacteria and fungi (Tiedje, 1988). Denitrifying bacteria are more numerous

The GenBank/EMBL/DDBJ accession numbers for the $16 \mathrm{~S}$ rRNA gene sequences of DR41_21 ${ }^{\top}$ and DR41_18 ${ }^{\top}$ are DQ665838 and D0665839, respectively. The accession numbers for the partial sequences of the DR41_21 ${ }^{\top}$ nirK gene, the DR41_18 $8^{\top}$ nirK gene and the DR41_21 $1^{\top}$ nosZ gene are AM279765, AM27976̄66 and AM279767, respectively.

An electron micrograph of a cell of strain DR41_21 $1^{\top}$, the effects of $\mathrm{pH}$, $\mathrm{NaCl}$ and temperature on the growth of the strain, the fatty acid and polar lipid compositions of strains DR41_18 ${ }^{\top}$ and DR41_21 ${ }^{\top}$, neighbour-joining phylogenetic trees for their nirK and nos $Z$ gene sequences and a graph of the growth of strain DR4 $1{ }_{2} 21^{\top}$ under anaerobiosis with nitrate and nitrite or nitrate, nitrite and nitrous oxide as electron acceptors are available as supplementary material with the online version of this paper. and active in the anaerobic layer of marine sediments than in the water column (Michotey et al., 2000). However, activities have been reported within water-column particles (Michotey \& Bonin, 1997). The eastern tropical Pacific Ocean, the eastern South Pacific Ocean and the Arabian Sea have been identified as major sites of water-column denitrification among the world's oceans (Anderson et al., 1982; Bange et al., 2000; Cline \& Richards, 1972; Codispoti \& Packard, 1980; Naqvi, 1994). This process can produce greenhouse gases, for example nitric and nitrous oxides, mainly in environments where denitrification is incomplete, such as in estuaries or in the bottom nepheloid layer (Bonin et al., 2002). In this paper, we describe two novel strains, belonging to the family Rhodospirillaceae, isolated from the water column in the Mediterranean Sea and which are potentially involved in denitrifying processes.

Samples were collected in February 2004 at the SOLA station located in the bay of Banyuls-sur-Mer $\left(42^{\circ} 29^{\prime} \mathrm{N}\right.$ $3^{\circ} 08^{\prime} \mathrm{E}$ ) at a depth of $3 \mathrm{~m}$. Dilution to extinction was 
performed according to Schut et al. (1993). Seawater for the preparation of media was collected at the sampling site, filtered through a $0.22 \mu \mathrm{m}$ polycarbonate membrane (Whatman) and then sterilized. Cultures were incubated in the dark at $20{ }^{\circ} \mathrm{C}$ for 4 weeks. Positive cultures were plated on seawater R2A agar (Difco) and incubated at $20{ }^{\circ} \mathrm{C}$ for 1 week. Colonies were picked and purified by means of at least three subcultures. Among these colonies, two isolates forming cream-coloured colonies were obtained and designated as strains DR41_21 ${ }^{\mathrm{T}}$ and DR41_18 ${ }^{\mathrm{T}}$.

Microscopic observations (AX70; Olympus) showed that cells from isolates DR41_21 $1^{\mathrm{T}}$ and DR41_18 ${ }^{\mathrm{T}}$ were motile rods which were approximately $2.5 \pm 0.6 \mu \mathrm{m}$ long and $0.9 \pm 0.2 \mu \mathrm{m}$ wide. Cells were negatively stained for transmission electron microscopy (Raguénès et al., 1997). Single polar flagella were observed for both strains (see Supplementary Fig. S1, available in IJSEM Online). The Ryu $\mathrm{KOH}$ reaction (Powers, 1995) led to immediate cell lysis, which was confirmed by light microscopy. This positive reaction indicated that both strains consisted of Gram-negative cells.

Isolates were grown in marine broth 2216 medium (MB; Difco). For the determination of salinity ranges, MB was prepared according to the composition provided by the manufacturer but with the appropriate $\mathrm{NaCl}$ concentration. To test the $\mathrm{pH}$ ranges for growth of the novel isolates, MES, PIPES, AMPSO or MOPS (Sigma) was added to MB to achieve the required $\mathrm{pH}$. Cultures were incubated at $30{ }^{\circ} \mathrm{C}$ under aerobic conditions. The methods used to determine the growth parameters for strains DR41_18 ${ }^{\mathrm{T}}$ and DR41_21 ${ }^{\mathrm{T}}$ were as reported by Wery et al. (2001b). Growth was observed at $15-44{ }^{\circ} \mathrm{C}$, the optimum temperature being $30{ }^{\circ} \mathrm{C}$ (see Supplementary Fig. S2 in IJSEM Online). The strains grew at $\mathrm{NaCl}$ concentrations ranging from 0 to $60 \mathrm{~g} \mathrm{l}^{-1}$, the optimum concentration being $20 \mathrm{~g} \mathrm{l}^{-1}$ (Supplementary Fig. S2). Growth occurred at pH 5.0-9.0; there was a clear optimum at $\mathrm{pH}$ 6.0. Growth decreased by $45 \%$ at $\mathrm{pH} 5.0$ relative to the value obtained at $\mathrm{pH} 6.0$, whereas a relative decrease of only $20 \%$ was observed at pH 7.0 (Supplementary Fig. S2). Both strains exhibited the same growth curves.

The ability of isolates DR41_21 ${ }^{\mathrm{T}}$ and DR41_18 $18^{\mathrm{T}}$ to use various substrates was investigated using Biolog GN2 MicroPlates (De Groote et al., 1999): the assessments were performed according to the manufacturer's instructions except that the incubation periods were made hourly over a $24 \mathrm{~h}$ period. The results for both strains were as follows: positive reactions were observed for fructose, glucose, raffinose, acetate, $\gamma$-hydroxybutyrate and propionate and weakly positive reactions were noted for mannitol, rhamnose, trehalose, xylitol and glycerol.

The enzymic activities of the two isolates were investigated using the API ZYM system (bioMérieux) according to the manufacturer's instructions. Positive reactions were obtained for alkaline phosphatase, acid phosphatase and leucine arylamidase for both strains.
Fatty acid methyl ester composition determinations were carried out by the identification service of the Deutsche Sammlung von Mikroorganismen und Zellkulturen (DSMZ; Braunschweig, Germany) (see Supplementary Fig. S3 in IJSEM Online). The fatty acid compositions for isolates DR41_18 ${ }^{\mathrm{T}}$ and DR41_21 $1^{\mathrm{T}}$ were $18: 1 \omega 7 c$ (67.6 and $69.1 \%$, respectively), $16: 1 \omega 7 c$ (14.1 and $13.9 \%$, respectively), 16:0 (10.6 and $11.3 \%$, respectively), 16:0 $3-\mathrm{OH}$ (1.0 and $1.1 \%$, respectively), 12:0 ALDE (1.1 and 1.0\%, respectively), 15:0 (not detected and 1.0\%, respectively), $17: 0$ (1.0 and $1.0 \%$, respectively) and $18: 03-\mathrm{OH}(1.0 \%$ and not detected, respectively). The large amounts of $18: 1 \omega 7 c$ and, to some extent, $16: 1 \omega 7 c$ and $16: 0$, were comparable with those found in Azospirillum oryzae and Azospirillum lipoferum. In contrast, 19:0 $\omega 8 c$ cyclo, 14:0 and 18:03-OH were not found in strain DR41_21 ${ }^{\mathrm{T}}$ and fatty acids 16:0 3-OH and 17:0 were 4-8-fold less represented than previously found for A. oryzae and $A$. lipoferum (Xie \& Yokota, 2005).

Analyses of respiratory quinones and polar lipids were carried out by the identification service of the DSMZ and Dr Brian Tindall (DSMZ). Both strains contained a ubiquinone (Q-10) system. The polar lipids were as follows: phosphatidylglycerol and an aminophospholipid running close to phosphatidylethanolamine (both strains), two undefined phospholipids for strain DR41_18 ${ }^{\mathrm{T}}$ and two undefined aminolipids for strain DR41_21 ${ }^{\mathrm{T}}$ (see Supplementary Fig. S4 in IJSEM Online). Comparisons of the lipid compositions and the polar lipids are presented in Table 1.

Table 1. Comparison of lipid compositions and polar lipid profiles of strains DR41_21 ${ }^{\top}$ and DR41_18 ${ }^{\top}$

\begin{tabular}{|lcc|}
\hline Lipid & DR41_21 & DR41_18 \\
\hline Fatty acids & & \\
16:0 3-OH & 1.1 & 1.0 \\
$18: 0$ 3-OH & - & 1.0 \\
$15: 0$ & 1.0 & - \\
$16: 0$ & 11.3 & 10.6 \\
$17: 0$ & 1.0 & 1.0 \\
$18: 0$ & - & 1.0 \\
$18: 1 \omega 7 c$ & 69.1 & 67.6 \\
$16: 1 \omega 7 c /$ iso-15 2-OH & 13.9 & 14.1 \\
10-Methyl 19:0 & 1.0 & - \\
19:0 $8 c$ cyclo & - & 1.8 \\
12:0 ALDE & 1.0 & 1.1 \\
Polar lipids & & \\
Phosphatidylglycerol & + & + \\
Unknown aminophospholipid 1 & + & + \\
Unknown aminophospholipid 2 & + & + \\
Unknown phospholipid 1 & - & + \\
Unknown phospholipid 2 & - & - \\
Unknown aminolipid 1 & + & - \\
Unknown aminolipid 2 & + & \\
\hline
\end{tabular}


Genomic DNA was extracted as described by Wery et al. (2001a). The DNA G+C content was determined by thermal denaturation using the method of Marmur \& Doty (1962) and the conditions described by Raguénès et al. (1997). The G $+C$ contents of the genomic DNA of strains DR41_21 ${ }^{\mathrm{T}}$ and DR41_18 ${ }^{\mathrm{T}}$ were $60.1 \pm 1.3 \mathrm{~mol} \%$ and $60.2 \pm 1.7 \mathrm{~mol} \%$, respectively. The $16 \mathrm{~S}$ rRNA genes were amplified and sequenced as described by Agogué et al. (2005) and the sequences were compared with those available in GenBank by using BLAST (Altschul et al., 1997). The sequences were analysed as described by Urios et al. (2006). Strains DR41_21 $1^{\mathrm{T}}$ and DR41_18 ${ }^{\mathrm{T}}$ (similarity value, $98.8 \%$ ) were found to be phylogenetically affiliated to the family Rhodospirillaceae in the class Alphaproteobacteria (Fig. 1). The closest relative was A. oryzae IAM $15130^{\mathrm{T}}$, having a similarity value of only $89 \%$. DNA-DNA hybridization was performed by the DSMZ identification service: the results indicated $55 \pm 0.5 \%$ DNA-DNA relatedness.

Due to the known metabolic capabilities of the closest relatives of strains DR41_18 ${ }^{\mathrm{T}}$ and DR41_21 ${ }^{\mathrm{T}}$, possible involvement in the nitrogen cycle was investigated. To amplify the narG, nirS, nirK, nos $Z$, nifH and amoA genes, the following published primers were used: na3F-narG5 ${ }^{\prime} \mathrm{R}$ (for narG; Goregues et al., 2005), cd3F-cd4R (for nirS;
Michotey et al., 2000), nirKCF-nirKCR (for nirK; Goregues et al., 2005), nosZ1211F-nosZ1897R (for nosZ; Rosch et al., 2002), nifHF-nifHR (for nifH; Zehr \& McReynolds, 1989), AmoA-1F-AmoA-2R (for amoA; Rotthauwe et al., 1997). PCR amplification was carried out with $20 \mu \mathrm{l}$ reaction mixture $\left(20 \mathrm{mM}\right.$ Tris/ $\mathrm{HCl}, 50 \mathrm{mM} \mathrm{KCl}, 1.5 \mathrm{mM} \mathrm{MgCl}_{2}$ ) containing $0.2 \mathrm{mM}$ each deoxyribonucleoside triphosphate, 160 pmol each primer and $0.5 \mathrm{U}$ Taq polymerase (Promega). For PCRs, 50 ng template DNA was used in the reaction. Amplification was performed with a mini-cycler (MJ Research) for 30 cycles. PCR cycles were performed as described previously (Goregues et al., 2005; Michotey et al., 2000; Rosch et al., 2002; Rotthauwe et al., 1997; Zehr \& McReynolds, 1989). Amplification products were analysed by means of electrophoresis on a $1 \%(w / v)$ agarose gel (Roche Diagnostics). Each PCR band was sequenced by MWG Biotech (Germany). The sequences were aligned with the same region of the sequence from the closest relative, using the BLASTN facility (http://www.ncbi.nlm. nih.gov/BLAST/) and sequences available in the GenBank database. Sequence alignment was achieved using CLUSTAL $\mathrm{W}$ (Thompson et al., 1994). The phylogenetic tree was constructed using the neighbour-joining method (Saitou \& Nei, 1987). Bootstrap analysis with 1000 replicates was used to check the robustness of the trees. Finally, the trees

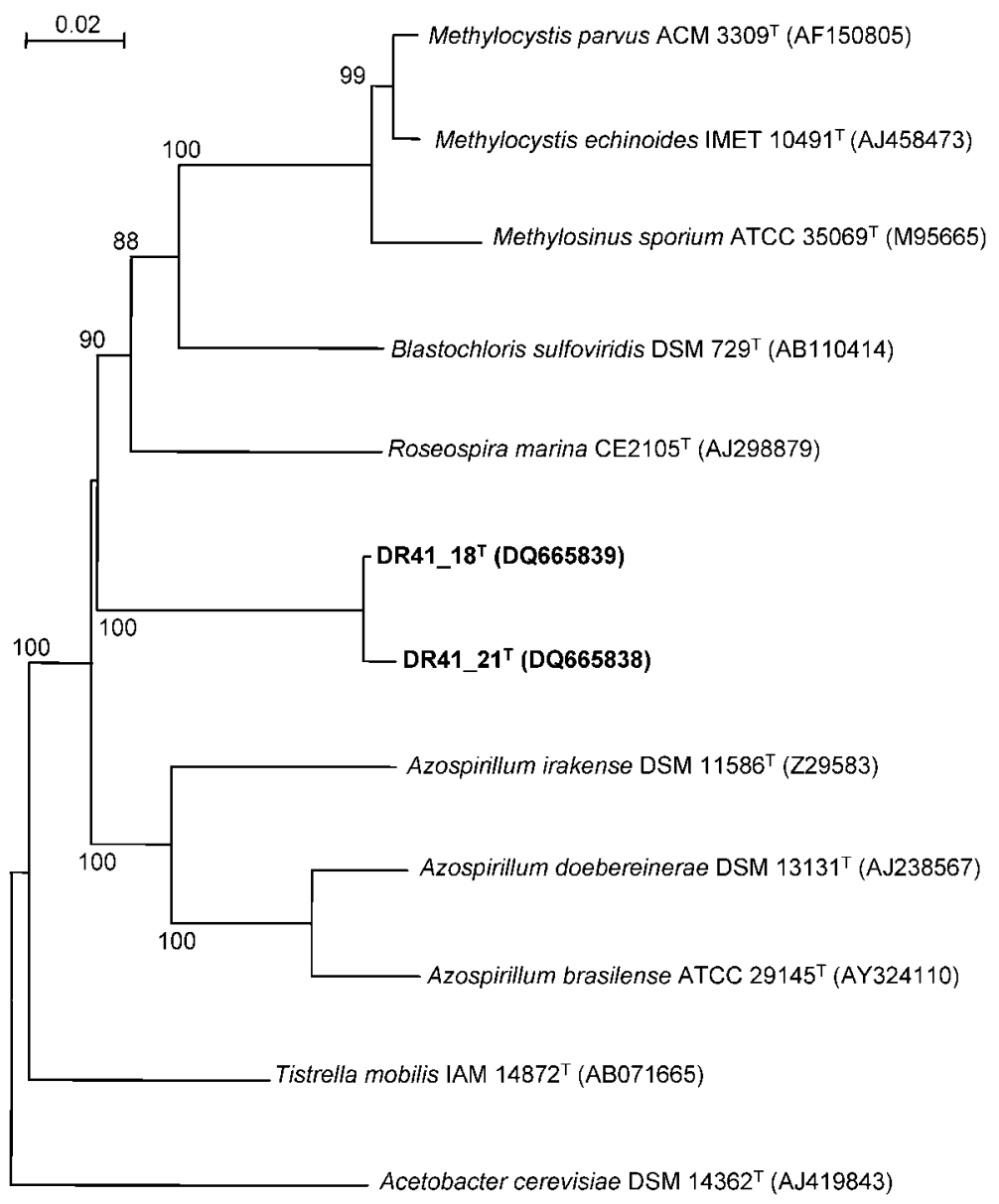

Fig. 1. Phylogenetic tree, based on $16 \mathrm{~S}$ rRNA gene sequences, showing the positions of strains DR41_18 ${ }^{\top}$ and DR41_21 $1^{\top}$. GenBank accession numbers and type strains are indicated. The tree corresponds to an unrooted tree obtained with the neighbour-joining algorithm (Kimura corrections). Bootstrap percentages (based on 1000 replications) are shown at branch points. Acetobacter cerevisiae was used as an outgroup. Bar, 0.02 changes per nucleotide position. 
were plotted using the NJPLOT program (Perrière \& Gouy, 1996).

Of the genes tested, only two relating to denitrification were successfully amplified using PCRs: nirK, coding for one of the nitrite reductases found in denitrifying bacteria, and nos $Z$, coding for the nitrous oxide reductase. The sequence analyses of these PCR products confirmed their affiliation to both nirK and nos $Z$ genes. The closest nirK representatives in GenBank corresponded to an environmental clone (GenBank accession no. DQ337782; sequence similarity of $80.6 \%$ ) and the closest representative from cultivated strains corresponded to the alphaproteobacterium Rhodobacter sphaeroides (U62291; sequence similarity of $73.4 \%$ ) (see Supplementary Fig. S5 in IJSEM Online). The closest nos $Z$ representatives in GenBank corresponded to alphaproteobacteria: Silicibacter pomeroyi (CP000032; $20.36 \%$ sequence similarity); Azospirillum brasilense sp7 (AF361791; 24.1\% sequence similarity) and Rhodobacter sp. denitrificans (F125260; $26.8 \%$ sequence similarity) (see Supplementary Fig. S6).

Anaerobic growth experiments were performed in $\mathrm{MB}$ supplemented with $0.15 \mathrm{mM}$ nitrate and $0.035 \mathrm{mM}$ nitrite, with or without $3.4 \mathrm{mM}$ nitrous oxide. The kinetics of nitrate, nitrite and nitrous oxide changes were followed during growth (see Supplementary Fig. S7 in IJSEM Online). Assays for $\mathrm{NO}_{3}^{-}, \mathrm{NO}_{2}^{-}$and $\mathrm{N}_{2} \mathrm{O}$ concentrations were carried out as described elsewhere (Goregues et al., 2005; Tréguer \& Le Corre, 1975). Physiological experiments confirmed the molecular results. Growth experiments revealed that strain DR41_21 $1^{\mathrm{T}}$ was able to utilize nitrate, nitrite and nitrous oxide as electron acceptors under anaerobiosis.

Some characteristics of strains DR41_21 ${ }^{\mathrm{T}}$ and DR41_18 were quite similar to those of their closest relatives, e.g. pleomorphic motile cells, the $\mathrm{pH}$ and temperature ranges for growth and some of the major fatty acids present. Nevertheless, strains DR41_21 ${ }^{\mathrm{T}}$ and DR41_ $18^{\mathrm{T}}$ were able to grow in a wider range of salinities than any related strain (Table 2) and had different fatty acid contents (Table 1).
The DNA G+C contents of strains DR41_21 ${ }^{\mathrm{T}}$ and DR41_18 ${ }^{\mathrm{T}}$ were $6-10 \mathrm{~mol} \%$ lower than those of their relatives. The most closely related strain shared only $89 \%$ $16 \mathrm{~S}$ rRNA gene sequence similarity. The closest nirK and nos $Z$ gene sequences were from taxa other than Azospirillum species. Strains DR41_21 $1^{\mathrm{T}}$ and DR41_18 differed from each other in terms of their lipid profiles, polar lipid compositions and nitrogen-cycle genes and showed a DNA-DNA relatedness of only $55 \%$.

On the basis of the phenotypic and genotypic differences between strains DR41_21 ${ }^{\mathrm{T}}$ and DR41_18 ${ }^{\mathrm{T}}$ and their closest recognized relatives, we propose that strains DR41_21 ${ }^{\mathrm{T}}$ and DR41_18 ${ }^{\mathrm{T}}$ should be assigned to two novel species of a new genus belonging to the family Rhodospirillaceae. In view of its marine origin and denitrification ability, the name Nisaea denitrificans gen. nov., sp. nov. is proposed for strain DR41_21 ${ }^{\mathrm{T}}$. As strain DR41_18 ${ }^{\mathrm{T}}$ possesses only nos $Z$ (encoding a nitrite reductase), the name Nisaea nitritireducens sp. nov. is proposed.

\section{Description of Nisaea gen. nov.}

Nisaea (Nis'ae.a. L. fem. n. Nisaea nymph of the sea, referring to the marine origin).

Motile, Gram-negative rods growing optimally at $30{ }^{\circ} \mathrm{C}$, pH 6.0 and $20 \mathrm{~g} \mathrm{l}^{-1} \mathrm{NaCl}$. The major fatty acids are $18: 1 \omega 7 c(69.1 \%), 16: 1 \omega 7 c(13.9 \%)$ and $16: 0(11.3 \%)$. Possess Q-10 and contain the polar lipid phosphatidylglycerol. Phylogenetically affiliated with the class Alphaproteobacteria within the family Rhodospirillaceae. The type species is Nisaea denitrificans.

\section{Description of Nisaea denitrificans sp. nov.}

Nisaea denitrificans [de.ni.tri.fi'cans. N.L. part. adj. denitrificans (from N.L. v. denitrifico) denitrifying].

The main characteristics are as those given in the genus description. In addition, cells are rods of $2.5 \pm 0.6 \mu \mathrm{m}$ long

Table 2. Characteristics that distinguish the novel strains from related genera

Taxa: 1, Azospirillum doebereinerae GSF $71^{\mathrm{T}}$ (Eckert et al., 2001); A. lipoferum ATCC $29707^{\mathrm{T}}$ (Sly et al., 1999); A. brasilense ATCC $29145^{\mathrm{T}}$ (Sly et al., 1999); Azospirillum halopraeferens DSM $3675^{\mathrm{T}}$ (Reinhold et al., 1987); A. oryzae IAM $15130^{\mathrm{T}}$ (Xie \& Yokota, 2005); Azospirillum melinis TMCY $0552^{\mathrm{T}}$ (Peng et al., 2006); Azospirillum canadense LMG 23617 ${ }^{\mathrm{T}}$ (Mehnaz et al., 2007); 2, Roseospira marina CE210 ${ }^{\mathrm{T}}$ (Guyoneaud et al., 2002); 3 , strains DR41_18 ${ }^{\mathrm{T}}$ and DR41_21 ${ }^{\mathrm{T}}$.

\begin{tabular}{|lccc|}
\hline Characteristic & $\mathbf{1}$ & $\mathbf{2}$ & $\mathbf{3}$ \\
\hline Sampling environment & Soil & Marine environment & Water column \\
DNA G $+\mathrm{C}$ content $(\mathrm{mol} \%)$ & $66.8-70.7$ & $65-72.3$ & 60.1 \\
Cell width $(\mu \mathrm{m})$ & $0.7-30$ & $1.5-6.0$ & $2-3 \times 0.9$ \\
Motility & + or - & + & + \\
Growth conditions: & $5-41(30-41)$ & $(30-35)$ & $15-44(30)$ \\
Temp. range (optimum) $\left({ }^{\circ} \mathrm{C}\right)$ & $0-<30(0-2.5)$ & $0.2-15(0.5-7)$ & $0-60(20)$ \\
Salinity range $\left(\right.$ optimum) $\left(\mathrm{g} \mathrm{l}^{-1}\right)$ & $3-8(6-7.2)$ & $5.3-8.5(6.7-7)$ & $5-9(6)$ \\
pH range (optimum) & & \\
\hline
\end{tabular}


and $0.9 \pm 0.2 \mu \mathrm{m}$ wide and have a single polar flagellum. Cream colonies are formed on marine agar medium. Growth occurs at $15-44{ }^{\circ} \mathrm{C}$ (optimum, $30^{\circ} \mathrm{C}$ ), at $\mathrm{pH} 5.0$ 9.0 (optimum, $\mathrm{pH}$ 6.0) and at salinities in the range 0 $60 \mathrm{~g} \mathrm{l}^{-1}$ (optimum, $20 \mathrm{~g} \mathrm{l}^{-1}$ ). Positive reactions with Biolog GN2 plates are obtained for fructose, glucose, raffinose, acetate, $\gamma$-hydroxybutyrate and propionate. Positive reactions with API ZYM are obtained for alkaline phosphatase, acid phosphatase and leucine arylamidase. Oxidase- and catalase-positive. The major fatty acids are $18: 1 \omega 7 c(69.1 \%), 16: 1 \omega 7 c(13.9 \%), 16: 0$ (11.3\%), $16: 0$ $3-\mathrm{OH}(1.1 \%), 12: 0 \operatorname{ALDE}(1.0 \%), 15: 0(1.0 \%)$ and $17: 0$ $(1.0 \%)$.

The type strain, DR41_21 ${ }^{\mathrm{T}}\left(=\right.$ DSM $18348^{\mathrm{T}}=\mathrm{CIP} 109265^{\mathrm{T}}$ $=$ OOB $129^{\mathrm{T}}$ ), was isolated from a water column in the bay of Banyuls-sur-Mer $\left(42^{\circ} 29^{\prime} N 3^{\circ} 08^{\prime} \mathrm{E}\right)$. The DNA G + C content of the type strain is $60 \mathrm{~mol} \%$.

\section{Description of Nisaea nitritireducens sp. nov.}

Nisaea nitritireducens [ni.tri.ti.re.duc' ens. N.L. nitris -itis nitrite; L. part. adj. reducens leading back, bringing back and (in chemistry) converting to a different oxidation state; N.L. part. adj. nitritireducens reducing nitrite].

The main characteristics are as those given in the genus description. In addition, cells are rods of $2.5 \pm 0.6 \mu \mathrm{m}$ long and $0.9 \pm 0.2 \mu \mathrm{m}$ wide with a single polar flagellum. Cream colonies are formed on marine agar medium. Positive reactions with Biolog GN2 plates are obtained for fructose, glucose, raffinose, acetate, $\gamma$-hydroxybutyrate and propionate. Positive reactions with API ZYM are obtained for alkaline phosphatase, acid phosphatase and leucine arylamidase. Oxidase- and catalase-positive. The major fatty acids are $18: 1 \omega 7 c(67.6 \%), 16: 1 \omega 7 c(14.1 \%), 16: 0$ $(10.6 \%), 16: 03-\mathrm{OH}(1.0 \%), 12: 0 \operatorname{ALDE}(1.1 \%)$ and $17: 0(1.0 \%)$.

The type strain, DR41_18 $\left(=\right.$ DSM $19540^{\mathrm{T}}=$ CIP $109601^{\mathrm{T}}$ $=\mathrm{OOB} 128^{\mathrm{T}}$ ), was isolated from a water column in the bay of Banyuls-sur-Mer $\left(42^{\circ} 29^{\prime} \mathrm{N}^{\circ} 08^{\prime} \mathrm{E}\right)$. The DNA G $+\mathrm{C}$ content of the type strain is $60 \mathrm{~mol} \%$.

\section{Acknowledgements}

This work was supported by the Equipe Mixte de Recherche linking the University Pierre et Marie Curie and the Centre National de la Recherche Scientifique to the Pierre Fabre Laboratories and the EU project BASICS (EVK3-CT-2002-00018). The project was also carried out within the framework of the MarBEF Network of Excellence 'Marine Biodiversity and Ecosystem Functioning', which is funded in the Community's Sixth Framework Programme (contract no. GOCE-CT-2003-505446). This publication is contribution number MPS-08017 of MarBEF. It was also partly funded by the French programme 'Bio-diversité et Changement Global project: development of a coastal microbial observatory' from the Institut Français de la Biodiversité (IFB-GICC, Paris, France). We are grateful to Magali Cros for her technical help with the physiological analyses.

\section{References}

Agogué, H., Casamayor, E. O., Bourrain, M., Obernosterer, I., Joux, F., Herndl, G. J. \& Lebaron, P. (2005). A survey on bacteria inhabiting the sea surface microlayer of coastal ecosystems. FEMS Microbiol Ecol 54, 269-280.

Altschul, S. F., Madden, T. L., Schaffer, A. A., Zhang, J., Zhang, Z., Miller, W. \& Lipman, D. J. (1997). Gapped BLAST and PSI-BLAST: a new generation of protein database search programs. Nucleic Acids Res 25, 3389-3402.

Anderson, J. J., Okubo, A., Robbins, A. S. \& Richards, F. A. (1982). A model for nitrite and nitrate distributions in oceanic oxygen minimum zones. Deep-Sea Res A 29, 1113-1140.

Bange, H. W., Rixen, T., Johansen, A. M., Siefert, R. L., Ramesh, R., Ittekkot, V., Hoffmann, M. R. \& Andreae, M. O. (2000). A revised nitrogen budget for the Arabian Sea. Global Biogeochem Cycles 14, 1283-1297.

Bonin, P., Tamburini, C. \& Michotey, V. (2002). Determination of the bacterial processes which are sources of nitrous oxide production in marine samples. Water Res 36, 722-732.

Cline, J. D. \& Richards, F. A. (1972). Oxygen deficient conditions and nitrate reduction in the eastern tropical North Pacific Ocean. Limnol Oceanogr 17, 885-900.

Codispoti, L. A. \& Packard, T. T. (1980). Denitrification rates in the eastern tropical South Pacific. J Mar Res 38, 453-477.

De Groote, D., van Doorn, L. J., Ducatelle, R., Verschuuren, A., Haesebrouck, F., Quint, W. G., Jalava, K. \& Vandamme, P. (1999). 'Candidatus Helicobacter suis', a gastric helicobacter from pigs, and its phylogenetic relatedness to other gastrospirilla. Int J Syst Bacteriol 49, 1769-1777.

Eckert, B., Weber, O. B., Kirchhof, G., Halbritter, A., Stoffels, M. \& Hartmann, A. (2001). Azospirillum doebereinerae sp. nov., a nitrogenfixing bacterium associated with the $\mathrm{C}_{4}$-grass Miscanthus. Int J Syst Evol Microbiol 51, 17-26.

Goregues, C. M., Michotey, V. D. \& Bonin, P. C. (2005). Molecular, biochemical, and physiological approaches for understanding the ecology of denitrification. Microb Ecol 49, 198-208.

Guyoneaud, R., Moune, S., Eatock, C., Bothorel, V., Hirschler-Rea, A., Willison, J., Duran, R., Liesack, W., Herbert, R. \& other authors (2002). Characterization of three spiral-shaped purple nonsulfur bacteria isolated from coastal lagoon sediments, saline sulfur springs, and microbial mats: emended description of the genus Roseospira and description of Roseospira marina sp. nov., Roseospira navarrensis sp. nov., and Roseospira thiosulfatophila sp. nov. Arch Microbiol 178, 315-324.

Marmur, J. \& Doty, P. (1962). Determination of the base composition of deoxyribonucleic acid from its thermal denaturation temperature. J Mol Biol 5, 109-118.

Mehnaz, S., Weselowski, B. \& Lazarovits, G. (2007). Azospirillum canadense sp. nov., a nitrogen-fixing bacterium isolated from corn rhizosphere. Int J Syst Evol Microbiol 57, 620-624.

Michotey, V. \& Bonin, P. (1997). Evidence for anaerobic bacterial processes in the water column: denitrification and dissimilatory nitrate ammonification in the northwestern Mediterranean Sea. Mar Ecol Prog Ser 160, 47-56.

Michotey, V., Mejean, V. \& Bonin, P. (2000). Comparison of methods for quantification of cytochrome $c d_{1}$-denitrifying bacteria in environmental marine samples. Appl Environ Microbiol 66, 1564-1571.

Naqvi, S. W. A. (1994). Denitrification processes in the Arabian Sea. In The Biogeochemistry of the Arabian Sea, pp. 181-202. Edited by D. Lal. Bangalore: Indian Academy of Sciences. 
Peng, G., Wang, H., Zhang, G., Hou, W., Liu, Y., Wang, E. T. \& Tan, Z. (2006). Azospirillum melinis sp. nov., a group of diazotrophs isolated from tropical molasses grass. Int J Syst Evol Microbiol 56, 1263-1271.

Perrière, G. \& Gouy, M. (1996). WWW-query: an on-line retrieval system for biological sequence banks. Biochimie 78, 364-369.

Powers, E. M. (1995). Efficacy of the Ryu nonstaining $\mathrm{KOH}$ technique for rapidly determining Gram reactions of food-borne and waterborne bacteria and yeasts. Appl Environ Microbiol 61, 3756-3758.

Raguénès, G., Christen, R., Guézennec, J., Pignet, P. \& Barbier, G. (1997). Vibrio diabolicus sp. nov., a new polysaccharide-secreting organism isolated from a deep-sea hydrothermal vent polychaete annelid, Alvinella pompejana. Int J Syst Bacteriol 47, 989-995.

Reinhold, B., Hurek, T., Fendrik, I., Pot, B., Gillis, M., Kersters, K., Thielemans, S. \& De Ley, J. (1987). Azospirillum halopraeferens sp. nov., a nitrogen-fixing organism associated with roots of Kallar grass (Leptochloa fusca (L.) Kunth). Int J Syst Bacteriol 37, 43-51.

Rosch, C., Mergel, A. \& Bothe, H. (2002). Biodiversity of denitrifying and dinitrogen-fixing bacteria in an acid forest soil. Appl Environ Microbiol 68, 3818-3829.

Rotthauwe, J. H., Witzel, K. P. \& Liesack, W. (1997). The ammonia monooxygenase structural gene $a m o A$ as a functional marker: molecular fine-scale analysis of natural ammonia-oxidizing populations. Appl Environ Microbiol 63, 4704-4712.

Saitou, N. \& Nei, M. (1987). The neighbour-joining method: a new method for reconstructing phylogenetic trees. Mol Biol Evol 4, 406-425.

Schut, F., de Vries, E. J., Gottschal, J. C., Robertson, B. R., Harder, W., Prins, R. A. \& Button, D. K. (1993). Isolation of typical marine bacteria by dilution culture: growth, maintenance, and characteristics of isolates under laboratory conditions. Appl Environ Microbiol 59, 2150-2160.

Sly, L. I., Taghavi, M. \& Fegan, M. (1999). Phylogenetic position of Chitinophaga pinensis in the Flexibacter-Bacteroides-Cytophaga phylum. Int J Syst Bacteriol 49, 479-481.
Thompson, J. D., Higgins, D. G. \& Gibson, T. J. (1994). ClUSTAL W: improving the sensitivity of progressive multiple sequence alignment through sequence weighting, position-specific gap penalties and weight matrix choice. Nucleic Acids Res 22, 4673-4680.

Tiedje, J. M. (1988). Ecology of denitrification and dissimilatory nitrate reduction to ammonium. In Biology of Anaerobic Microorganisms, pp. 179-227. Edited by A. J. B. Zehnder. New York: Wiley.

Tréguer, P. \& Le Corre, P. (1975). Manuel d'Analyse des Sels Nutritifs dans l'Eau de Mer (Utilisation de l'Autoanalyser 2 Technicon), pp. 1110. Brest: Université de Bretagne Occidentale.

Urios, L., Agogue, H., Lesongeur, F., Stackebrandt, E. \& Lebaron, P. (2006). Balneola vulgaris gen. nov., sp. nov., a member of the phylum Bacteroidetes from the north-western Mediterranean Sea. Int J Syst Evol Microbiol 56, 1883-1887.

Wery, N., Lesongeur, F., Pignet, P., Derennes, V., Cambon-Bonavita, M., Godfroy, A. \& Barbier, G. (2001a). Marinitoga camini gen. nov., sp. nov., a rod-shaped bacterium belonging to the order Thermotogales, isolated from a deep-sea hydrothermal vent. Int $J$ Syst Evol Microbiol 51, 495-504.

Wery, N., Moricet, J., Cueff, V., Jean, J., Pignet, P., Lesongeur, F., Cambon-Bonavita, M. \& Barbier, G. (2001b). Caloranaerobacter azorensis gen. nov., sp. nov., an anaerobic thermophilic bacterium isolated from a deep-sea hydrothermal vent. Int J Syst Evol Microbiol 51, 1789-1796.

Xie, C. H. \& Yokota, A. (2005). Azospirillum oryzae sp. nov., a nitrogen-fixing bacterium isolated from the roots of the rice plant Oryza sativa. Int J Syst Evol Microbiol 55, 1435-1438.

Zehr, J. P. \& McReynolds, L. A. (1989). Use of degenerate oligonucleotides for amplification of the nifH gene from the marine cyanobacterium Trichodesmium thiebautii. Appl Environ Microbiol 55, 2522-2526. 